\title{
Engaging Youth Voices To Create Supportive School Environments For Healthy Eating And Physical Activity
}

\section{Louise L Hardy}

Western Sydney Local Health District

Kym Rizzo Liu

Western Sydney Local Health District

Emma Sainsbury

Western Sydney Local Health District

Smita Shah ( $\sim$ Smita.Shah@health.nsw.gov.au )

Western Sydney Local Health District

\section{Research Article}

Keywords: Youth voice, high school students, leadership, healthy eating, physical activity

Posted Date: January 13th, 2022

DOI: https://doi.org/10.21203/rs.3.rs-1179018/v1

License: (c) (i) This work is licensed under a Creative Commons Attribution 4.0 International License. Read Full License 


\section{Abstract}

Background: The Students As LifeStyle Activists (SALSA) Program is an effective Australian peer-led leadership program offered to high schools. SALSA Youth Voices (SYV) is a novel extension of the SALSA program, providing SALSA Peer Leaders with an opportunity to further develop leadership skills, and to design and implement an intervention to promote healthy eating and physical activity within their school. The objectives of this study were to 1) measure the acceptability of the SYV program, 2) determine skills gained by peer leaders from participating in SYV, and 3) determine whether peer leaders successfully implemented a student-designed healthy eating/physical activity intervention.

Methods: Schools which participated in the SALSA program in 2019 were invited to a Leadership Day workshop (Term 3) where SALSA Peer Leaders identified and planned an activity to promote healthy eating and/or physical activity at their school, and an Action Day (Term 4) where peer leaders presented their interventions to 100 health and education professionals. Peer leaders completed two brief online surveys at the end of the Leadership Day and upon registration at the Action Day.

Results: Eighty-four peer leaders (aged 14-15 years) from seven high schools in western Sydney (mean Index of Community Socio-Educational Advantage (ICSEA) $=951$ ) participated in SYV. Peer leaders reported their involvement with the SYV program as positive, with $68 \%$ rating it as "very valuable". Skills gained by the peer leaders included teamwork (90\%), communication (85\%), leadership (77\%) and confidence (65\%). Peer leaders planned and devised interventions included installing water refill stations, improving school gyms, redesigning girls' sports shorts, and other strategies to engage girls in physical activity. Most peer leaders reported their intervention was successfully implemented and sustainable in their school.

Conclusions: SYV provides a unique leadership opportunity for students from socio-economically disadvantaged areas to be effective agents of change to create opportunities for students to participate in physical activity and improve healthy food options at school.

\section{Background}

Adolescents can be influential agents of personal and community change and should be given more prominence in health decisions and health promotion initiatives that affect them [1,2]. The concept of youth voice considers the perspectives, ideas, experiences, knowledge, and actions of young people [3]. Youth voice programs provide leadership opportunities for young people, especially among youth from socially disadvantaged communities whose voices are often not heard. Human behaviour models posit that opportunities to voice one's own opinions and to influence decision-makers is strongly connected to individual wellbeing and empowerment [4].

Schools have long recognised the significance and value of involving students in school decision-making and have actively promoted this within education policy and practice [2]. When students are given a voice in a safe environment such as schools it shows them that their contributions matter and they are valued 
[1]. It also assists students to develop a range of pro-social and emotional skills that prepare them for adulthood [5, 6]. In New South Wales (NSW, Australia) the Wellbeing Framework for Schools focuses on giving students a voice, becoming active learners and developing strong character qualities that will enable them to succeed, thrive and contribute positively throughout life [2].

The Students As LifeStyle Activists (SALSA) program is an effective Australian peer-led leadership program offered to high schools [7-9]. The SALSA program is the only peer-led leadership program in NSW high schools delivered for no cost through a local health district in partnership with local medical associations and the NSW Department of Education. Although any high school may participate, the SALSA program targets high schools in low socio-economic areas.

The SALSA program applies the socio-ecological model to influence health behaviours and build capacity in students to advocate for change in their schools, homes, and neighbourhoods $[9,10]$. The program uses a peer-led approach to motivate high school students to make healthy lifestyle choices that focus on increasing physical activity and healthy food choices. These behaviours were selected because both are sub-optimal in Australian adolescents [11-13], and barriers to improving these behaviours are higher among adolescents from low socio-economic areas [14]. The lesson content of the program is linked to Stage 4 and 5 of the NSW Personal Development, Health and Physical Education curriculum [15]. Accordingly, students learn to (1) think critically, solve problems, and make informed decisions on health, safety, wellbeing, and physical activity; (2) explore issues that impact the health, safety, and wellbeing of themselves and others and; (3) participate in movement experiences that are regular, varied, purposeful, challenging, and enjoyable.

The program involves a three-step process: (1) SALSA educators (trained university students) coach volunteer Year 10 students as SALSA Peer Leaders during a one-day workshop held at schools; (2) SALSA Peer Leaders, in teams of four, deliver $4 \times 60$-minute lessons to Year 8 students using a video, games and activities; (3) participating students are encouraged to create an individual SMART (i.e. specific, measurable, achievable, relevant and time-bound) goal and a 'School Action Plan' to improve eating and physical activity environments in their school.

SALSA Youth Voices (SYV) was conceptualised in 2016, when schools participating in the SALSA program expressed an interest in peer leaders being further involved in leadership training and civic engagement. In line with the socio-ecological framework [9], the aim was for peer leaders to identify and develop activities within their local community that would help them to choose healthy foods and be more physically active. In many cases the activities selected by the peer leaders required significant budgets, involved multiple community organisations, and were not on the local councils' operational plans. As a result, these activities proposed by peer leaders were not realised.

To ensure peer leaders' proposed ideas were likely to be achieved, SYV was modified in 2019 from students identifying barriers in the local community, to identifying an issue within their school environment. The aim of SYV 2019 was to provide SALSA Peer Leaders with an opportunity to further develop leadership skills while creating a supportive environment within their school. The objectives of 
this study were to (1) measure the acceptability of the SYV program; (2) determine skills gained by peer leaders from participating in SYV; and (3) determine whether peer leaders were able to successfully implement a student-designed intervention that supports healthy eating and/or physical activity.

\section{Methods}

The SALSA program and the SYV have ethics approval from the University of Sydney Human Research Ethics Committee (approval number: 2018/272) and the NSW Department of Education (SERAP approval number: 2014096). The programs involve a voluntary whole-of-school approach which is supported by the Department of Education. Ethics approval was awarded by the University of Sydney Human Research Ethics Committee allowing exemption of written consent by students for participation. Students were able to withdraw their participation at any time.

Sixteen high schools which participated in the SALSA program in 2019 were invited to participate in SYV. The ICSEA score (mean 1000, SD 100) was sourced from the My School website [16]. SYV comprised of two half day events: a Leadership Day workshop in Term 3 and an Action Day in Term 4.

\section{Leadership Day}

The workshop was held at a professional sports club (the Greater Western Sydney Giants) and delivered by the SALSA team and the club's sports development team. A teacher from each school accompanied the peer leaders at the workshop.

The workshop content involved a combination of presentations, group discussion and interactive games/activities addressing topics such as 1) "why youth voices?"; 2) barriers to and enablers of adolescent physical activity and healthy eating; 3 ) skills needed to develop a school action plan; and 4) planning for change within their school environment.

Peer leaders were provided with an Action Plan template (Supplementary Figure 1) to guide the planning, delivery, and evaluation of their intervention in their school. Peer leaders worked in school groups with their teacher to identify an intervention they wanted to implement. They then presented their ideas at the end of the workshop. Peer leaders were encouraged to own their intervention i.e. students conceptualised the idea, set up the project, and engaged with teachers for advice, discussion, and support.

\section{Action Day}

The Action Day provided a forum for peer leaders to showcase the outcomes of the interventions they implemented in their schools. It was held in an auditorium at a local hospital. The students presented their school-based intervention to an audience of over 100 health and education professionals.

\section{Project evaluation}

Peer leaders completed a brief evaluation survey following the Leadership Day workshop and upon registration at the Action Day (Supplementary Figures 2 and 3). Process evaluation included (1) why 
students participated in the SYV program; (2) which workshop activities they enjoyed; (3) how helpful the activities were in developing a School Action Plan; and (4) the overall perceived value of the SYV program. Impact evaluation included 1) whether the school action plan was implemented; (2) challenges faced by the peer leaders and (3) perceived skills gained from participation in SYV. Study data were collected and managed using the REDCap electronic data capture tool [17] hosted at the University of Sydney. Due to the small numbers, descriptive statistics were used to summarise the results.

\section{Results}

Sixteen high schools participated in the SALSA program and 309 Year 10 students (age 14-15 years) trained to be peer leaders in 2019. Of these, seven schools (44\%) and 84 SALSA Peer Leaders $(27 \%)$ participated in SYV. Table 1 summarises the school characteristics and peer leaders participating in SYV. One school was for girls only, six were coeducational, and the average ICSEA of participating schools was 951 (range 870-1021) with the total school student enrolments ranging from 476 to 1075.

[INSERT Table 1]. Characteristics of schools participating in SYV

Table 1

Characteristics of school participating in SYV

\begin{tabular}{|c|c|c|c|c|}
\hline \multicolumn{5}{|c|}{2019 school characteristics } \\
\hline \# & ICSEA & Sex & Total school enrolment (n) & Total Year 10 enrolments (n) \\
\hline 1 & 1021 & Girls & 780 & 103 \\
\hline 2 & 870 & Mixed & 476 & 95 \\
\hline 3 & 907 & Mixed & 730 & 151 \\
\hline 4 & 911 & Mixed & 631 & 90 \\
\hline 5 & 978 & Mixed & 1009 & 162 \\
\hline 6 & 1,011 & Mixed & 761 & 142 \\
\hline 7 & 961 & Mixed & 1075 & 188 \\
\hline \multicolumn{5}{|c|}{ ICSEA = Index of Community Socio-Educational Advantage (mean 1000, SD 100) } \\
\hline
\end{tabular}

Eighty-four peer leaders participated in the Leadership Day workshop. Of these, 51 (61\% response rate, girls $=67 \%$ ) completed the Leadership Day evaluation survey. Figure 1 shows peer leaders' responses as to why they volunteered to be part of Leadership Day. The most common response was that they wanted to strengthen their leadership skills.

[INSERT Figure 1]. Reasons why peer leaders volunteered to participate in SYV $(n=51)$ 
Most $(77 \%)$ of the peer leaders reported that the School Action Plan template (Supplementary Figure 1) provided to help guide the designing of an intervention at their school was very useful. Two-thirds (68\%) reported that the workshop activities were helpful in designing and planning their intervention, and $65 \%$ reported they were very confident that their intervention would be implemented.

Following the workshop, peer leaders reported building skills such as teamwork (90\%), communication (85\%), leadership (77\%), and confidence (65\%) (Figure 2). Less than half of the peer leaders reported building skills for advocacy and problem solving.

[INSERT Figure 2]. Peer leaders' perceived skills developed at the Leadership Day workshop $(n=51)$ and from participating in SYV $(n=28)$

\section{Action Day}

Thirty-six peer leaders (43\%) were selected by their school to present on Action Day. A description of the peer leader designed interventions, rationale, and outcomes are shown in Table 2. Collectively, four interventions aimed to increase physical activity participation among girls at their school. The strategies included redesigning girls' sport shorts, providing non-traditional and less competitive sports, forming a girls' volleyball team, and redeveloping the school gym to be amenable to girls. Two interventions involved improving access to drinking water and the installation of water filling stations, with one school designing a re-usable water bottle. Two schools organised lunchtime activities and access to sports equipment, and two schools focused on reopening and refurbishing their school gyms. Most of the intervention activities required peer leaders to scope and source service providers in their local community, including a retail franchise to design unisex sports shorts and a local health district to contribute to funding water filling stations. 
Table 2

Interventions, including rationale and outcomes designed (and described) by peer leader

\begin{tabular}{|c|c|c|c|}
\hline School \# & Intervention & Rationale & Process/ Outcome \\
\hline 1 & Gala Sports Day & $\begin{array}{l}\text { To increase the } \\
\text { numbers of girls } \\
\text { participating in } \\
\text { physical activity } \\
\text { at the school, } \\
\text { including non- } \\
\text { traditional and } \\
\text { less competitive } \\
\text { sports. }\end{array}$ & $\begin{array}{l}\text { This intervention was } \\
\text { meant to be implemented } \\
\text { late in } 2020 \text {. However, } \\
\text { cOVID-19 impacted on its } \\
\text { delivery. As a result, the } \\
\text { gala day was postponed. }\end{array}$ \\
\hline 2 & $\begin{array}{l}\text { Table tennis tournament with healthy } \\
\text { snacks provided }\end{array}$ & $\begin{array}{l}\text { The school had } \\
\text { table tennis } \\
\text { equipment that } \\
\text { was rarely used. } \\
\text { Students were } \\
\text { not eating fresh } \\
\text { fruit or drinking } \\
\text { water. }\end{array}$ & $\begin{array}{l}\text { Held a } \\
\text { table tennis tournament } \\
\text { (Triple T Project) and } \\
\text { prepared free fresh fruit } \\
\text { cups and water for } \\
\text { students. }\end{array}$ \\
\hline 3 & $\begin{array}{l}\text { Revamp and update school gym for } \\
\text { junior and senior students }\end{array}$ & $\begin{array}{l}\text { Majority } \\
\text { of students were } \\
\text { unaware of the } \\
\text { existence of the } \\
\text { school gym. } \\
\text { The equipment } \\
\text { was inadequate } \\
\text { and } \\
\text { outdated. }\end{array}$ & $\begin{array}{l}\text { This intervention was } \\
\text { planned for } 2020 \text {. However, } \\
\text { COVID- } 19 \text { impacted on its } \\
\text { progress and the } \\
\text { refurbishing of the gym will } \\
\text { be revisited in } 2022 \text {. }\end{array}$ \\
\hline 4 & Sports at lunchtime & $\begin{array}{l}\text { To provide } \\
\text { students with a } \\
\text { weekly sports } \\
\text { competition } \\
\text { during lunchtime } \\
\text { and access to } \\
\text { equipment to } \\
\text { play games } \\
\text { including } \\
\text { basketball, } \\
\text { football, soccer, } \\
\text { and volleyball. }\end{array}$ & $\begin{array}{l}\text { A weekly } \\
\text { competition 'Sports at } \\
\text { Lunch Time' (SALT) and } \\
\text { access to sports equipment } \\
\text { during lunch time. } \\
\text { A girls volleyball team was } \\
\text { formed. }\end{array}$ \\
\hline
\end{tabular}




\begin{tabular}{|c|c|c|c|}
\hline School \# & Intervention & Rationale & Process/ Outcome \\
\hline \multirow[t]{4}{*}{5} & \multirow[t]{4}{*}{$\begin{array}{l}\text { Install water refilling stations and } \\
\text { design a school water bottle }\end{array}$} & \multirow{3}{*}{$\begin{array}{l}\text { To increase } \\
\text { students' water } \\
\text { intake } \\
\text { throughout the } \\
\text { day and to } \\
\text { reduce the } \\
\text { number of soft } \\
\text { drinks purchased } \\
\text { at the school } \\
\text { canteen. }\end{array}$} & $\begin{array}{l}\text { Students sought quotes } \\
\text { from third party providers } \\
\text { for water refill stations. }\end{array}$ \\
\hline & & & $\begin{array}{l}\text { Fruit snacks were sold at } \\
\text { school to raise } \\
\$ 150 \text { AUD towards } \\
\text { water refill stations and } \\
\text { to provide healthier food } \\
\text { options for students. }\end{array}$ \\
\hline & & & $\begin{array}{l}\text { Three water refill } \\
\text { stations were installed. }\end{array}$ \\
\hline & & $\begin{array}{l}\text { A school water } \\
\text { bottle to } \\
\text { encourage } \\
\text { students to drink } \\
\text { more water and } \\
\text { reduce plastic } \\
\text { waste. }\end{array}$ & $\begin{array}{l}\text { Water bottles were } \\
\text { designed with the school } \\
\text { logo and a tag for each } \\
\text { student's name. }\end{array}$ \\
\hline \multirow[t]{3}{*}{6} & \multirow[t]{3}{*}{$\begin{array}{l}\text { Physical activity during breaks, better } \\
\text { access to drinking water and } \\
\text { redesign of girls' sports shorts }\end{array}$} & $\begin{array}{l}\text { To increase } \\
\text { physical activity } \\
\text { participation } \\
\text { during breaks. }\end{array}$ & $\begin{array}{l}\text { A new weekly sporting } \\
\text { system during breaks called } \\
\text { Let's Move at Lunchtime } \\
\text { was initiated. }\end{array}$ \\
\hline & & $\begin{array}{l}\text { To provide } \\
\text { students } \\
\text { with access to } \\
\text { drinking water at } \\
\text { the school oval. }\end{array}$ & $\begin{array}{l}\text { A water refill station } \\
\text { installed near the school } \\
\text { oval. }\end{array}$ \\
\hline & & $\begin{array}{l}\text { Unisex sports } \\
\text { shorts } \\
\text { were unsuitable } \\
\text { including } \\
\text { an extremely } \\
\text { long crotch that } \\
\text { was better suited } \\
\text { for boys. }\end{array}$ & $\begin{array}{l}\text { Researched style ideas, } \\
\text { surveyed girls in Years 7-10, } \\
\text { pitched idea to P\&C } \\
\text { meeting. Modern design } \\
\text { made including stretchy } \\
\text { and breathable material. } \\
\text { Engaged a local vendor to } \\
\text { make and sell } \\
\text { new sports shorts (cost } \\
\text { AUD\$35-40). }\end{array}$ \\
\hline \multirow[t]{2}{*}{7} & \multirow[t]{2}{*}{ To refurbish the school gym } & $\begin{array}{l}\text { The gym } \\
\text { equipment was } \\
\text { unsafe. }\end{array}$ & $\begin{array}{l}\text { Purchase of new gym } \\
\text { equipment }\end{array}$ \\
\hline & & $\begin{array}{l}\text { Equipment was } \\
\text { disorganised and } \\
\text { broken. }\end{array}$ & $\begin{array}{l}\text { Equipment organised neatly } \\
\text { and correctly. }\end{array}$ \\
\hline
\end{tabular}




\begin{tabular}{|c|c|c|c|}
\hline School \# & Intervention & Rationale & Process/ Outcome \\
\hline & & $\begin{array}{l}\text { Wire entrance } \\
\text { doors that } \\
\text { moved left to } \\
\text { right allowed dirt } \\
\text { and leaves to } \\
\text { blow into gym. }\end{array}$ & $\begin{array}{l}\text { New roller doors installed to } \\
\text { provide more space. }\end{array}$ \\
\hline & & $\begin{array}{l}\text { Aimed to } \\
\text { increase female } \\
\text { participation in } \\
\text { physical activity. }\end{array}$ & $\begin{array}{l}\text { Specific gym times have } \\
\text { been made available to } \\
\text { female students. }\end{array}$ \\
\hline
\end{tabular}

[INSERT Table 2]. Interventions, including rationale and outcomes designed (and described) by peer leaders

Twenty-eight peer leaders (78\% response rate, girls $=86 \%$ ) completed the evaluation survey. Peer leaders from six of the seven schools reported that their activity worked "really well" and should continue the following year. Peer leaders from one school reported their intervention (reopening the school gym) was to be completed the following year due to the time taken for approval, purchasing of equipment and installation. The most common challenges peer leaders encountered while developing and implementing their interventions were communicating the activity to other students (36\%) and lack of time $(29 \%)$ (Figure 3).

[INSERT Figure 3]. Challenges encountered by participants in developing and implementing their school action plan $(n=28)$

Overall, $68 \%$ of peer leaders rated their involvement in SYV as "very valuable". Most peer leaders identified that SYV helped build skills in leadership, communication, confidence, and teamwork (Figure 2). Only a quarter of peer leaders indicated that they developed advocacy skills. Qualitative feedback from peer leaders highlighted the benefits of participating in the SYV program, as indicated below:

"It provides a voice for all youths-upgrading our creativity and leadership skills."

"The SALSA program provides me with confidence when it comes to advocating for our school action plan. It gave me an idea of what it's like to be a leader and promote a healthy lifestyle."

"We were able to learn new information as well as educate others. We were able to use problem solving skills to interact with our peers and discuss how to install a water refill station."

\section{Discussion}

To our knowledge, SYV is the only Australian peer-led leadership program offered to high school students from socio-economically disadvantaged areas which engages and empowers them to conceptualise and design an intervention to promote healthy eating and physical activity at school. The findings indicate that SYV was highly acceptable to students, and had the potential to improve healthy food and physical 
activity environments at their school. The program also enhanced the leadership, communication, and teamwork skills of students; a similar result to other international peer-led leadership programs [18].

There is strong evidence to suggest that the development of skills such as leadership, teamwork and communication helps to prepare adolescents for post-school achievements and the workforce [19-21]. Further, participating in leadership roles as an adolescent has been shown to improve a student's chances for a tertiary education and builds a foundation for future leadership opportunities [22]. This is of particular importance for students from lower socio-economic status (SES) areas, given evidence showing poorer learning outcomes and lower ambition to achieve a tertiary education compared with students from higher SES areas [23]. Offering SYV to schools in low SES areas is therefore one strategy for helping to achieve equitable outcomes for students. Whilst we invited all 16 schools to participate in SYV, only the first seven schools who responded were invited due to limited capacity and availability of the facilities where the training occurred.

Capturing student voices has been shown to be a powerful and effective tool for school planning and improvement $[23,24]$. The school action plans developed by students were realistic and achievable, with the potential to positively impact the whole school community. Over 5000 students were enrolled at the seven participating high schools at the time the study was conducted, highlighting the significant reach of these interventions. Despite all but one of the schools being co-educational, most of the interventions focussed on increasing participation in physical activity among girls. This probably reflects the greater proportion of girls compared to boys participating in the SYV program. The Australian Government's Physical Activity Recommendations for Children and Young People recommend children (aged 5 to 17 years) undertake a minimum 60 minutes of moderate to vigorous activity each day $[25,26]$. However, population data from 146 countries (including Australia) show that $81 \%$ of adolescents aged $11-17$ years are not meeting physical activity guidelines [27]. Prevalence of insufficient physical activity was highest amongst girls aged 11-17 years, with the data indicating no significant improvement in girls' physical activity levels since 2001 [27]. The health interventions designed in SYV are therefore of great importance for helping to correct gender disparities in physical activity levels.

In contrast to most school-based health promotion initiatives, SYV was neither researcher nor teacher-led. Rather, it is student-centred, which may have contributed to the peer leaders taking ownership of their interventions. Peer leaders' engagement in SYV may also have been positively influenced because it was delivered by external professionals (i.e. a local health district and a sporting club) rather than teachers. Another unique feature of the SYV program is that peer leaders were not selected based on popularity among their peers. Students volunteered to participate, which helps ensure the program is accessible to all interested students.

The main reason for modifying SYV in 2019 was to ensure that the ideas developed by the students were actioned. Considerations for the future should include conducting follow-up with the schools to assess the sustainability of the students' interventions and their impacts on changing students' food and physical activity preferences and participation at school. 
Approximately $40 \%$ of students felt that communicating their activity to other students was a challenge in designing and implementing their action plan. Further, the proportion of students who identified gaining advocacy skills from the program was low (33\%). Greater focus on activities to help build advocacy skills of students could be one area of improvement for future workshops.

The majority of the participants who took part in SYV were girls, indicating the need to consider ways of recruiting and engaging boys in the program. Finally, future programs should consider how to increase post-survey evaluation completion rates. Possible strategies include using both paper-based and electronic surveys (link provided via QR code), explaining clearly when the evaluation surveys are to be completed, and encouraging teachers to oversee the process.

\section{Conclusion}

SYV offered a unique opportunity for high school students from socio-economically disadvantaged areas to build teamwork, communication, and leadership skills, and be agents of change to create a school environment which supports physical activity and healthy eating. Students were empowered to action their own health priorities, resulting in benefits for the whole school community. The SYV model could be applied to other health issues facing adolescents.

\section{Declarations}

\section{Ethics approval and consent to participate}

The SALSA and SYV programs obtained ethics approval from the University of Sydney Human Research Ethics Committee (approval number: 2018/272) and the NSW Department of Education (SERAP approval number: 2014096). All methods were carried out in accordance with relevant guidelines and regulations, including the National Statement on Ethical Conduct in Human Research (2007). The SALSA and SYV programs involve a voluntary whole-of-school approach which is supported by the Department of Education. The University of Sydney Human Research Ethics Committee exempted the requirement for written consent by students for participation

\section{Consent for publication}

Not applicable.

\section{Availability of data and materials}

All data generated or analysed during this study are included in this published article and its supplementary information files.

\section{Competing interests}

The authors declare that they have no competing interests. 


\section{Funding}

The Program is supported by a philanthropic donation (Patricia McAlary and Family).

\section{Authors' contributions}

SS, KRL and LH conceptualised the project. LH was involved in the acquisition, analysis and interpretation of the data, and drafted the manuscript. ES, KRL and SS contributed to drafting the manuscript. All authors read and approved the final manuscript.

\section{Acknowledgements}

The authors would like to thank the schools and students involved in the study, Rooty Hill High School Principal Christine Cawsey, Blacktown, Hills and Mt Druitt Medical Associations, Western Sydney Primary Health Network and the McAlary family for their support.

\section{References}

1. Greenwald, H.P., et al., Youth Development, Community Engagement, and Reducing Risk Behavior. Journal of Primary Prevention, 2006. 27(1): p. 3.

2. NSW Department of Education and Communities, The Wellbeing Framework for Schools. 2015: Sydney.

3. Hadfield, M. and K. Haw, 'Voice', young people and action research. Educational Action Research, 2001. 9(3): p. 485-502.

4. Cantor, N. and C.A. Sanderson, 12 life task participation and well-being: The importance of taking part in daily life. Well-being: Foundations of hedonic psychology, 2003. 230.

5. Knowles-Yánez, K.L., Children's participation in planning processes. Journal of Planning Literature, 2005. 20(1): p. 3-14.

6. Mitra, D.L., The significance of students: can increasing" student voice" in schools lead to gains in youth development? Teachers college record, 2004. 106: p. 651-688.

7. Foley, B., et al., Evaluation of a peer education program on student leaders' energy balance-related behaviors. BMC public health, 2017. 17(1): p. 695.

8. Shrewsbury, V.A., et al., Impact and cost of the peer-led Students As LifeStyle Activists programme in high schools. Health Education Journal, 2020. 79(1): p. 3-20.

9. Shah, S., et al., The Students As LifeStyle Activists (SALSA) program. British Journal of Sports Medicine, 2017. 51(19): p. 1445.

10. Davison, K.K. and L.L. Birch, Childhood overweight: a contextual model and recommendations for future research. Obesity reviews, 2001. 2(3): p. 159-171.

11. Hardy, L.L., et al., NSW schools physical activity and nutrition survey (SPANS). 2017: NSW Department of Health. 
12. Hardy, L.L., et al., Children's adherence to health behavior recommendations associated with reducing risk of non-communicable disease. Preventive Medicine Reports, 2017. 8: p. 279-285.

13. Boylan, S., et al., Assessing junk food consumption among Australian children: trends and associated characteristics from a cross-sectional study. BMC Public Health, 2017. 17(1): p. 299.

14. Peralta, L.R., et al., Influence of School-Level Socioeconomic Status on Children's Physical Activity, Fitness, and Fundamental Movement Skill Levels. Journal of School Health, 2019. 89(6): p. 460467.

15. NSW Education Standards Authority, NSW Syllabus for the Australian Curriculum: Personal Development, Health and Physical Education K-10 Syllabus. 2018, NSW Education Standards Authority: Sydney.

16. Australian Curriculum Assessment and Reporting Authority. My Schoo/ß. 25/08/2020]; Available from: http://www.myschool.edu.au.

17. Harris, P.A., et al., Research electronic data capture (REDCap) - A metadata-driven methodology and workflow process for providing translational research informatics support. J Biomed Inform, 2009. 42(2): p. 377-81.

18. Shook, J.L. and J.R. Keup, The benefits of peer leader programs: An overview from the literature. New directions for higher education, 2012. 2012(157): p. 5-16.

19. Gaines, R. and M. Mohammed, Soft skills development in K-12 education. 2013, Georgia Leadership Institute for School Improvement..

20. UNICEF, Global evaluation of life skills education programmes. New York: United Nations Children's Fund, 2012.

21. Villarreal, S., et al., Leadership styles predict career readiness in early college high-school students. Psychology in the Schools, 2018. 55(5): p. 476-489.

22. Murphy, S.E. and S.K. Johnson, The benefits of a long-lens approach to leader development: Understanding the seeds of leadership. The Leadership Quarterly, 2011. 22(3): p. 459-470.

23. Thomson, S., et al., PISA 2018: Reporting Australia's Results. Volume I, Student Performance. Australian Council for Educational Research (ACER). 2019.

24. Manefield, J., et al., Student voice: A historical perspective and new directions (Paper No. 10). East Melbourne, Victoria. Office of Learning and Teaching, Department of Education, 2007.

25. Australian Government Department of Health. Physical activity guidelines for children and young people (aged 5 to 17 years). 2021; Available from: https://www.health.gov.au/health-topics/physicalactivity-and-exercise/physical-activity-and-exercise-guidelines-for-all-australians/for-children-andyoung-people-5-to-17-years.

26. Department of Health. Physical activity and exercise guidelines for all Australians: For children and young people (5 to 17 years). 202125 October 2021]; Available from: https://www.health.gov.au/health-topics/physical-activity-and-exercise/physical-activity-andexercise-guidelines-for-all-australians/for-children-and-young-people-5-to-17-years. 
27. Guthold, R., et al., Global trends in insufficient physical activity among adolescents: a pooled analysis of 298 population-based surveys with 1.6 million participants. The Lancet Child \& Adolescent Health, 2020. 4(1): p. 23-35.

\section{Figures}

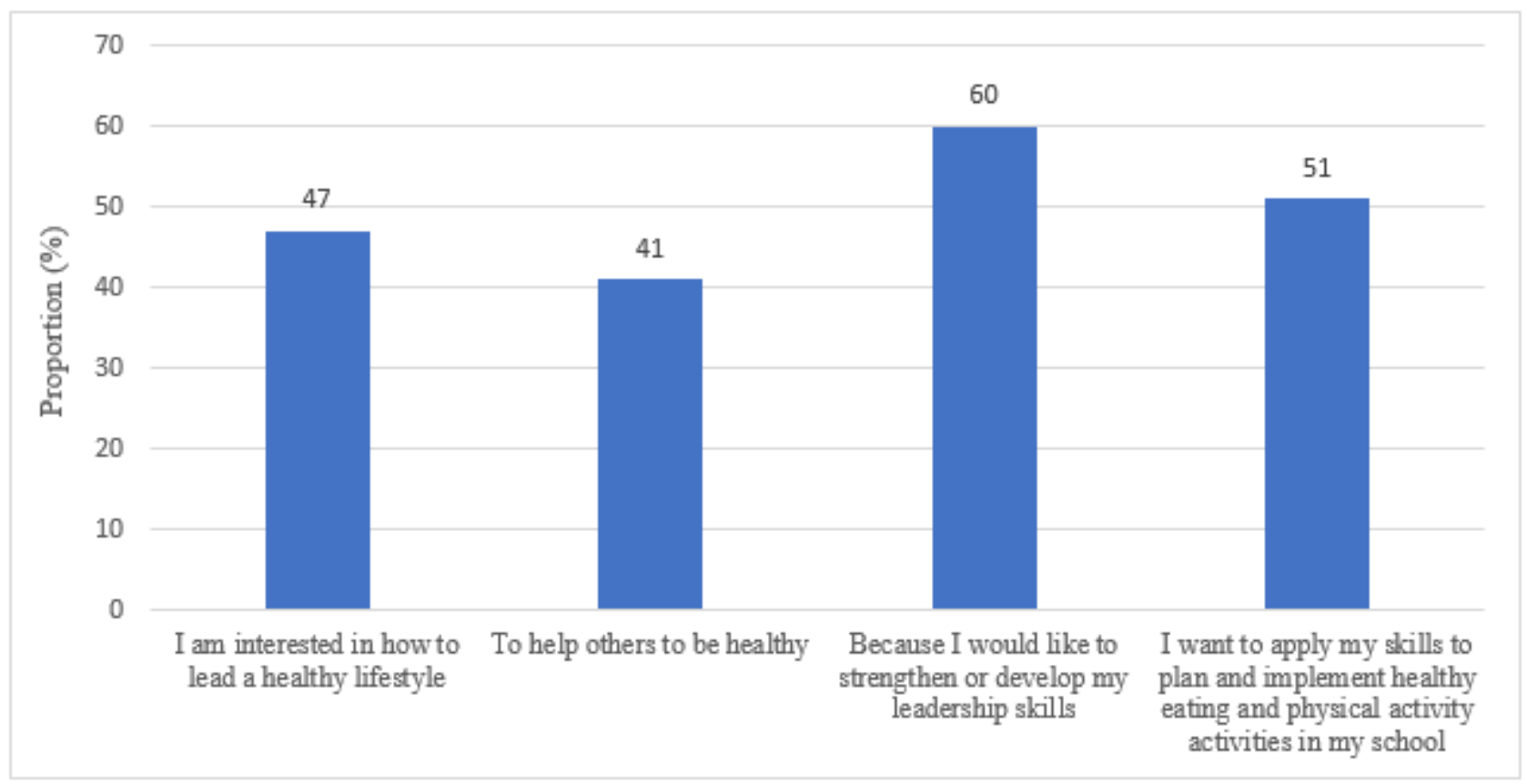

\section{Figure 1}

Reasons why peer leaders volunteered to participate in SYV $(n=51)$ 


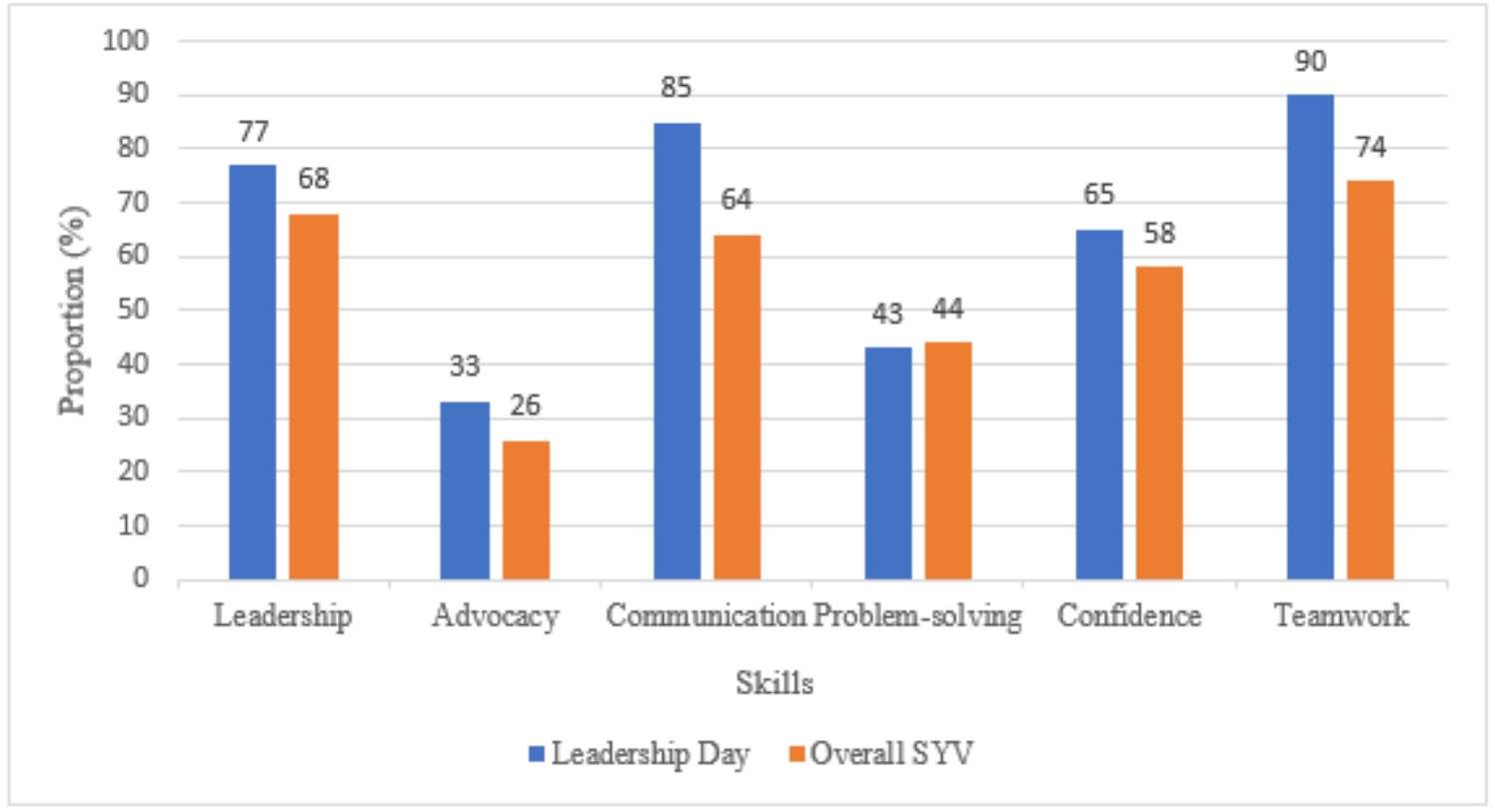

Figure 2

Peer leaders perceived skills developed at the Leadership Day workshop $(n=51)$ and from participating in SYV $(n=28)$

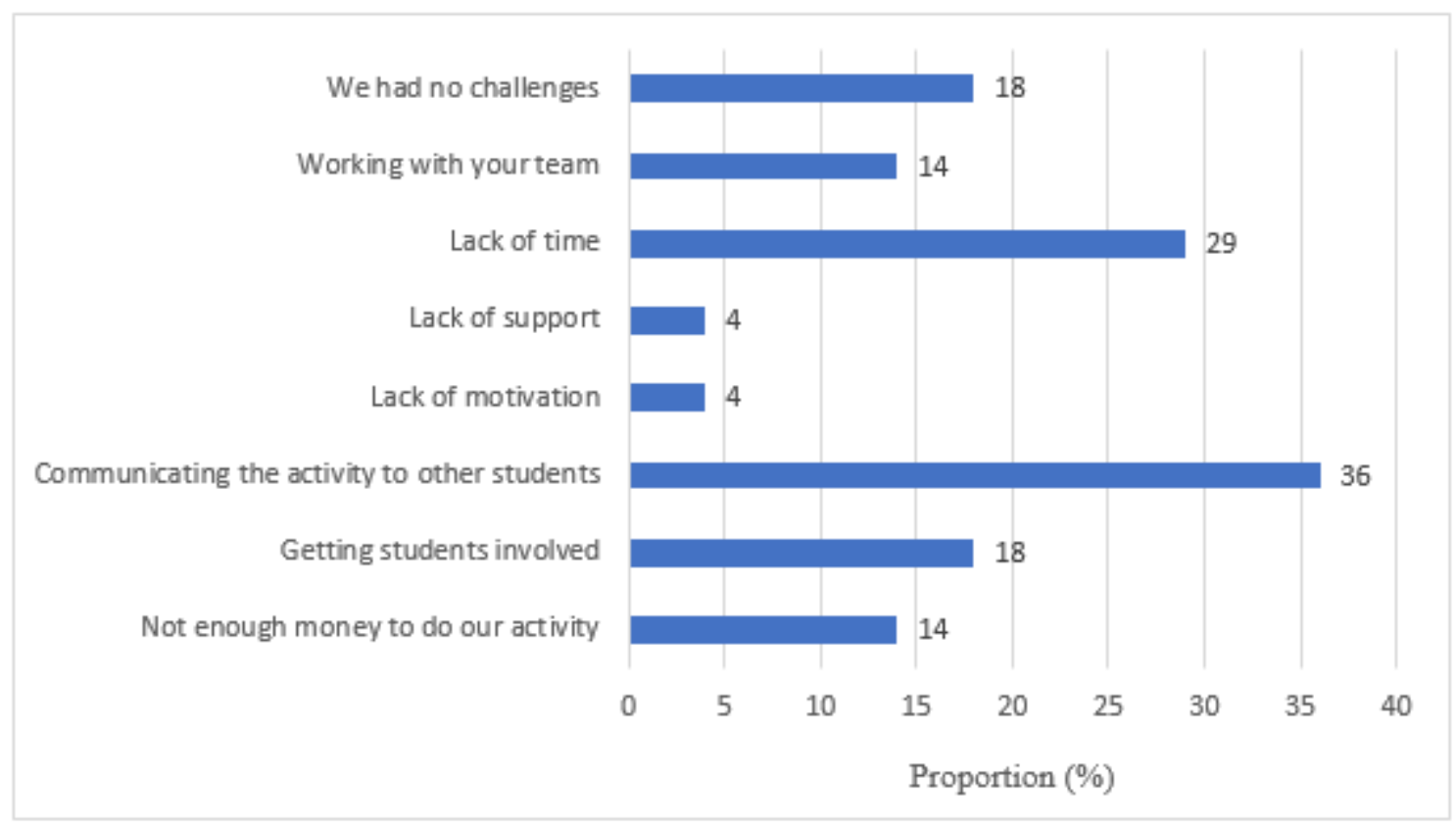

Figure 3

Challenges encountered by peer leaders in designing and implementing the intervention $(n=28)$ 


\section{Supplementary Files}

This is a list of supplementary files associated with this preprint. Click to download.

- SALSAYouthVoicesSupplementaryFigures.docx

- Supplemetaryfilestudyrawdata.xlsx 